\title{
The Holocene occurrence of cold water corals in the NE Atlantic: Implications for coral carbonate mound evolution
}

\author{
Norbert Frank ${ }^{\mathrm{a}, *}$, Estelle Ricard ${ }^{\mathrm{a}}$, Audrey Lutringer-Paquet ${ }^{\mathrm{a}}$, Cees van der Land ${ }^{\mathrm{d}}$, Christophe Colin ${ }^{\mathrm{b}}$, \\ Dominique Blamart ${ }^{\mathrm{a}}$, Anneleen Foubert ${ }^{\mathrm{c}, \mathrm{e}}$, David Van Rooij ${ }^{\mathrm{c}}$, Jean-Pierre Henriet ${ }^{\mathrm{c}}$, \\ Henk de Haas ${ }^{\mathrm{d}}$, Tjeerd van Weering ${ }^{\mathrm{d}}$
}

a LSCE, Laboratoire des Sciences du Climat et de L'Environnement-IPSL/CEA-CNRS-UVSQ Bât. 12, Avenue de la Terrasse, 91198 Gif-sur-Yvette, France

b IDES, Laboratoire des Interactions et Dynamique des Environnements de Surface, UMR-CNRS, Université Paris XI, Bât. 504 Géologie, 91405 Orsay, France

${ }^{c}$ Renard Centre of Marine Geology, Department of Geology and Soil Science, Ghent University, Krijgslaan 281 S8, B-9000 Gent, Belgium

d NIOZ, Royal Netherlands Institute for Sea Research, P.O. Box 59, NL-1790 AB den Burg. Texel, Netherlands

e Department of Earth and Environmental Sciences, K.U. Leuven, Celestijnenlaan 200E, B-3001 Heverlee, Belgium

\section{A R T I C L E I N F O}

\section{Article history:}

Received 30 June 2008

Received in revised form 4 August 2009

Accepted 6 August 2009

Available online 22 August 2009

Communicated by G.J. de Large

\section{Keywords:}

carbonate mound

deep sea corals

U-series dating

climate

Rockall Bank

Porcupine Seabight

\begin{abstract}
A B S T R A C T
U-series dating of constructional cold-water corals is a powerful tool to reconstruct the evolution of corals on carbonate mounds. Here we have investigated the time framework of corals such as Lophelia pertusa and Madrepora oculata on five different mound settings of the eastern North Atlantic (on Rockall Bank and in Porcupine Seabight), sampled at variable depth and location (610-880 m water depth). We have found that the past $11 \mathrm{ka}$ reflect a period generally favourable for coral development. We further determined local mound growth rates and identified mound surface erosion (framework collapse) during times of active coral framework construction. "Local" vertical mound growth rates vary between less than $5 \mathrm{~cm} \mathrm{ka}^{-1}$ and up to $220 \mathrm{~cm} \mathrm{ka}^{-1}$. We interpret rates exceeding $15 \mathrm{~cm} \mathrm{ka}^{-1}$ as representative of densely populated coral reefs. During times of reduced or absent coral development, mound evolution rates are by far smaller $(0$ to $<5 \mathrm{~cm}$ $\mathrm{ka}^{-1}$ ). The time resolution achieved here furthermore provides first evidence for reduced coral (ecosystem) activity at 1.8-2.0 ka, 4.2-4.8 ka and between 6 and $8.2 \mathrm{ka}$ within the Holocene that may be related to climate driven changes of the coral growth environments. During Glacial periods coral growth in those areas seems apparently extremely reduced or is even absent on mounds.
\end{abstract}

(c) 2009 Elsevier B.V. All rights reserved.

\section{Introduction}

Extensive deep-water coral ecosystems exist along the northeast Atlantic continental margins of Ireland, Scotland and Norway (Freiwald and Roberts, 2005). Since about a decade these deep-water coral reefs are subject to extensive European research efforts to better constrain ecosystem functioning and coral reef development (Henriet et al., 1998; Hovland et al., 1998; de Mol et al., 2002; Dorschel et al., 2005; Freiwald and Roberts, 2005; White et al., 2005; Roberts et al., 2006; van Rooij et al., 2006; Dorschel et al., 2007; Mienis et al., 2007; Wheeler et al., 2007). These mounds can achieve a height of several hundred meters and measure several square kilometres at the base (Hovland et al., 1994; de Mol et al., 2002; Huvenne et al., 2003; Kenyon et al., 2003; van Weering et al., 2003). The sedimentary environment is complex due to strong directional bottom water currents (White et al., 2005; Mienis et al., 2007). The main framework builders are known to be the branching corals Lophelia pertusa and Madrepora oculata also associated with other species such as the solitary coral Desmophyllum dianthus. Much progress

\footnotetext{
* Corresponding author. Tel.: +3316982 43 58; fax: +3316982 3568 . E-mail address: Norbert.Frank@cea.fr (N. Frank).
}

has been made on our understanding of coral reproduction, food web and environmental factors steering modern coral growth (see Roberts et al. (2006) and for review (Roberts et al., 2009). IODP 307 expedition in the Porcupine Seabight has further revealed that a carbonate mound in Porcupine Seabight (Challenger Mound) is entirely the result of deepwater coral growth since about 2.6 Ma ago (Williams et al., 2006; Kano et al., 2007). But mound evolution is discontinuous, diagenesis is important, and mounds are shaped through erosion ones coral growth is absent (Rüggeberg et al., 2003; Frank et al., 2005; Dorschel et al., 2005; Foubert et al., 2007; Kano et al., 2007).

Deep-water corals can be accurately dated by means of U-series dating (Smith et al., 1997; Adkins et al., 1998; Mangini et al., 1998; Lomitschka and Mangini, 1999; Cheng et al., 2000a; Schröder-Ritzrau et al., 2003; Frank et al., 2004; Frank et al., 2005; Schröder-Ritzrau et al., 2005), which provides a tool to determine the age-depth relationship of coral fragments.

Dating coral fragments from "on-mound sediment cores" allows to determine Vertical Mound Growth Rates (VMGR) in cases were such cores represent the successive growth and degradation of the open coral framework (Frank et al., 2005; de Haas et al., 2009). It further allows measuring the timing above and below hiatuses often invisible 
in the sedimentary record (Rüggeberg et al., 2003; Dorschel et al., 2005; Frank et al., 2005; Rüggeberg et al., 2007; Eisele et al., 2008). Finally, dating provides a direct measure of the timing of open framework construction and thus reveals periods favourable of coral growth i.e. with respect to major climate change. Moreover, dating of corals is important to provide a time framework needed for paleoenvironmental studies that can be carried out on coral skeletons.

Here, we present a detailed chronological survey based on mass spectrometric U-series dating of constructional deep-water coral fragments. The primary objective is to determine (i) the time framework of coral growth on different mounds, i.e. in different mound provinces and environments, (ii) to provide measures of the local vertical mound growth rates and (iii) to provide further evidence of the geological mound processes such as erosion and diagenesis. We also demonstrate for the first time that "almost continues coral age records can be established" needed to carry out paleo-environmental studies.

\section{Environmental setting}

The Rockall Trough and Rockall Bank form part of the British and Irish continental margin consisting of several deep basins, separated by basement ridges. Within Porcupine Seabight, along Porcupine Bank and on Rockall Bank, numerous carbonate mound provinces have been found at water depth between $400 \mathrm{~m}$ and $1100 \mathrm{~m}$ (Hovland et al., 1994; de Mol et al., 2002; Huvenne et al., 2003; Kenyon et al., 2003; van Weering et al., 2003; Wheeler et al., 2005; van Rooij et al., 2006; van Wheeler et al., 2007; Foubert et al., 2007; Huvenne et al., 2007).

Today, the hydrodynamic regime within those mound areas is stipulated through strong bottom currents driven by northward moving Eastern North Atlantic Water (ENAW) (Rockall Bank) and Mediterranean Overflow Water (MOW) (solely in Porcupine Seabight) both overlying Labrador Sea Water (LSW) which re-circulates at depth below 1200 m (Ellett and Martin, 1973; Huthnance, 1986; van Aken and Becker, 1996; Holliday et al., 2000; New and SmytheWright, 2001). In addition, the local topography results in internal basin scales waves and internal tides favoring nutrient and food storage in mound regions (White and Bowyer, 1997; White et al., 2005; Mienis et al., 2007). Strong wind forcing through the westerlies result in a deep mixed layer during winter time that may occasionally reach down to $1000 \mathrm{~m}$ depth and which occurs over several months (Holliday et al., 2000). Consequently, corals develop in well ventilated near thermocline waters of generally $4-12{ }^{\circ} \mathrm{C}$, close or within the oxygen minimum zone. In addition to large scale oceanographic patterns local hydrodynamic regimes can influence the coral reef settings and in particular organic matter supply and storage near the reef area (White et al., 2005). This is done through deflection of the main currents along the topographic structure resulting in anticyclonic recirculation and potentially the creation of Taylor columns (isopycnal doming over an obstacle on the mounds) and/or Ekman drainage along the mound flanks (White et al., 2005).

\section{Material and methods}

\subsection{Core locations}

During the $R / V$ Marion Dufresne cruise "MD123" in September 2001, 5 gravity cores have been taken at various depths close to the summit of Mounds Perseverance, Challenger, and Thérèse in Porcupine Seabight and on two unnamed mounds on Rockall Bank (Table 1 and Fig. 1).

On Rockall Bank gravity cores MD01-2454G (54G) and MD012455G (55G) were taken at $747 \mathrm{~m}$ and $637 \mathrm{~m}$ water depth (Table 1, Fig. 1a). Both mounds are part of two mound clusters on the margin of Rockall Bank close to each other (van Rooji et al., 2001). These mounds, part of the Logachev mound province (Mienis et al., 2009;
Table 1

Gravity core locations (see Fig. 1).

\begin{tabular}{|c|c|c|c|c|}
\hline Core & Coordinates & $\begin{array}{l}\text { Depth } \\
\text { (m) }\end{array}$ & $\begin{array}{l}\text { Length } \\
(\mathrm{m})\end{array}$ & Site \\
\hline (1) MD01-2454G & $\begin{array}{l}55^{\circ} 31^{\prime} \mathrm{N} \\
15^{\circ} 39^{\prime} \mathrm{W}\end{array}$ & 747 & 2.73 & $\begin{array}{l}\text { Top unnamed mound - } \\
\text { Southwest Rockall Bank }\end{array}$ \\
\hline (2) MD01-2455G & $\begin{array}{l}55^{\circ} 33^{\prime} \mathrm{N} \\
15^{\circ} 40^{\prime} \mathrm{W}\end{array}$ & 637 & 1.93 & $\begin{array}{l}\text { Top unnamed mound - } \\
\text { Southwest Rockall Bank }\end{array}$ \\
\hline (3) MD01-2459G & $\begin{array}{l}52^{\circ} 18^{\prime} \mathrm{N} \\
13^{\circ} 03^{\prime} \mathrm{W}\end{array}$ & 610 & 10.79 & $\begin{array}{l}\text { Top mound Perseverance - } \\
\text { Northern Porcupine Seabight }\end{array}$ \\
\hline (4) MD01-2463G & $\begin{array}{l}51^{\circ} 26^{\prime} \mathrm{N} \\
11^{\circ} 46^{\prime} \mathrm{W}\end{array}$ & 888 & 10.75 & $\begin{array}{l}\text { Top mound Therese - } \\
\text { Eastern Porcupine Seabight }\end{array}$ \\
\hline (5) MD01-2451G & $\begin{array}{l}51^{\circ} 23^{\prime} \mathrm{N} \\
11^{\circ} 46^{\prime} \mathrm{W}\end{array}$ & 762 & 12.84 & $\begin{array}{l}\text { Top mound Challenger - } \\
\text { Eastern Porcupine Seabight }\end{array}$ \\
\hline
\end{tabular}

Wheeler et al., 2007) (Fig. 1a), reflect a flourishing coral ecosystem with abundant associated fauna. The coring location of $54 \mathrm{G}$ lies in fact between the summits of two small south-north elongated mounds, near a lithified hardground outcrop observed during Victor dive 10 of the Caracole campaign (Olu Le-Roy and Shipboard Scientific Crew, 2002). Core 55G was recovered close to the top on the northern steep flank of the south-north elongated mound (Fig. 1a). Both cores did recover solely a small part $(2.73 \mathrm{~m}$ and $1.73 \mathrm{~m})$ of the initially anticipated length (18 m and $13 \mathrm{~m}$ depth) due to the presence of hardgrounds through which the gravity cores could not penetrate. Hardgrounds were not recovered, but have been sampled in several piston cores taken previously in close vicinity during the $R / V$ Pelagia cruise 64PE182 (van Weering and shipboard scientific party, 1999; de Haas et al., 2009).

Gravity core MD01-2459G (59G) was taken on Mound Perseverance in Porcupine Seabight. Situated in the Magellan Mound province mainly consisting of buried mounds (de Mol et al., 2002; Huvenne et al., 2005), this mound is one of few to reach above the sea floor. It has a southwest-northeast elongated shape and an active coral fauna of Lophelia pertusa and Desmophyllum dianthus corals (Olu Le-Roy, 2004; Huvenne et al., 2005) (Fig. 1b). Core 59G was sampled on the south-western flank and no live corals have been recovered (Fig. 1b). Gravity core MD01-2451G (51G, 762 m depth) was recovered on top of Challenger Mound within the Belgica Mound province, which has a south-north elongated shape and rises about $153 \mathrm{~m}$ above the seabed (Williams et al., 2006; Kano et al., 2007) (Fig. 1c). Today, this mound is covered by dead coral rubble in contrast to the flourishing coral ecosystems recorded on Thérèse Mound (Olu Le-Roy, 2004; de Mol et al., 2007) and Galway Mound (Foubert et al., 2005; Eisele et al., 2008) situated nearby but at deeper depth (Williams et al., 2006). The core was taken on the north-western tip of the summit off the mound flank facing the northward moving currents and it is situated next to the site of recent IODP drilling 307 (Fig. 1c). Gravity core MD012463G (63G, $888 \mathrm{~m}$ ) was recovered from top of Thérèse Mound (Fig. 1d). This mound has again a south-north elongated shape (Wheeler et al., 2005; Williams et al., 2006) and is covered with a strikingly active coral ecosystem (Olu Le-Roy, 2004). Sampling occurred slightly on the eastern flank close to the top of the mound near the presently active L. pertusa and Madrepora oculata coral ecosystem (Fig. 1d), which reaches from the south-western flank to the top with dense coral populations (Olu Le-Roy, 2004). Overall, sediment coring within Porcupine Seabight using gravity corers has been very successful on mounds as most cores achieved the initially anticipated length. But core MD01-2459G hit a carbonate hardground layer that was recovered at $10 \mathrm{~m}$ core depth.

All cores from SW Rockall Bank and within Porcupine Seabight have been investigated on board R/V Marion Dufresne using a GEOTEK Multi Sensor core Logger at a resolution of $2 \mathrm{~cm}$, measuring magnetic susceptibility (Barlington loop senor MS2B) and GRAPE density ( $\mathrm{Cs}^{137}$ source with energies principally at $0.622 \mathrm{MeV}$ ) on whole round sections. Then, cores were send to University Bordeaux to perform X-ray 


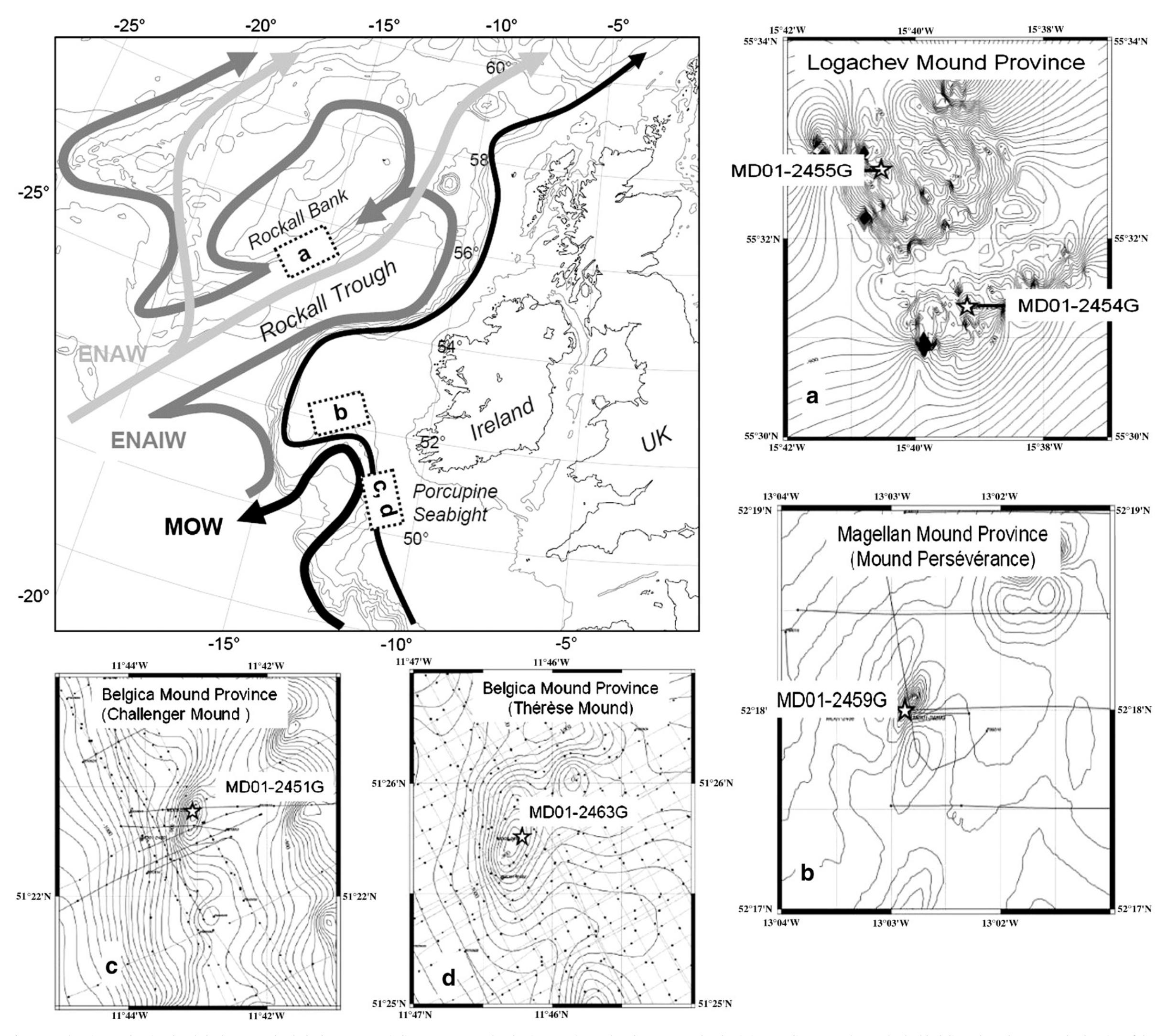

Fig. 1. Core locations and regional scale bathymetry. The dashed grey arrows indicate eastern North Atlantic water (ENAW) and eastern North Atlantic intermediate water (ENAIW). The black lines show the present day location of the MD01-2454G is taken between two small mound features and core MD01-2455G is taken on the northern steep flank of an unnamed mound. b) Mound Perseverance (Porcupine Seabight): situated in a rather flat area of the Magellan Moun

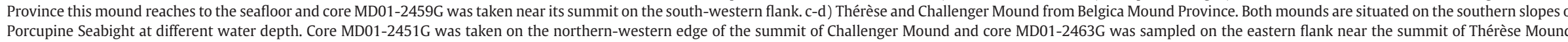


radiographies using the SCOPIX X-ray equipment (DGO UMR5805) (Foubert et al., 2007), which provides constrains on coral content and distribution (Fig. 2). Following a first evaluation of the coral abundance and core physical parameters corals have been selected for U-series dating and to determine coral species and state of preservation. In the following we focus solely on the upper most coral rich core sections to study the most recent recorded coral growth interval.

\subsection{Mass spectrometric ${ }^{230} \mathrm{Th} / \mathrm{U}$ dating of coral skeletons}

The technique of U-series dating of deep-water corals follows closely previously published procedures (Frank et al., 2004; Frank et al., 2005). Mass spectrometric analyses were carried out on the LSCE (Gif-sur-Yvette, France) thermal ionization mass spectrometer (Finnigan MAT262).

Reference material HU-1 was used to determine the internal reproducibility of $U$ and Th isotope analyses with values identical to the ones previously published (Frank et al., 2005). Activity ratios were calculated from measured atomic ratios using the decay constants of ${ }^{238} \mathrm{U},{ }^{234} \mathrm{U}$ and
${ }^{230} \mathrm{Th}$ of $\lambda_{238}=1.5515 .10^{-10}$ years $^{-1}, \lambda_{234}=2.8263 .10^{-6}$ years $^{-1}$, $\lambda_{230}=9.1577 .10^{-6}$ years $^{-1}$ (Cheng et al., 2000b), respectively. In total, 75 samples from 5 sediment cores have been investigated by U-series dating, with the Rockall Bank cores (55G and 54G) being the most intensively studied $(n=50)$. In total, 7 U-series ages have been rejected due to significant contamination $\left(>10 \mathrm{ng} \mathrm{g}^{-1}\right.$ ) with ${ }^{232} \mathrm{Th}$.

To complete the coral growth records in cases, a few AMS ${ }^{14} \mathrm{C}$ ages were measured. Those AMS ${ }^{14} \mathrm{C}$ ages have been obtained according to the procedures described by (Frank et al., 2004) and have been calibrated using the marine ${ }^{14} \mathrm{C}$ calibration of CALIB510 (Stuiver et al., 1998 ) with a mean sub-surface water reservoir age of $500 \pm 100$ a (Frank et al., 2004).

\section{Results}

\subsection{U-series dating results}

Results of U-series dating of coral fragments are presented in Table 2. The U concentration of cold-water species Lophelia pertusa
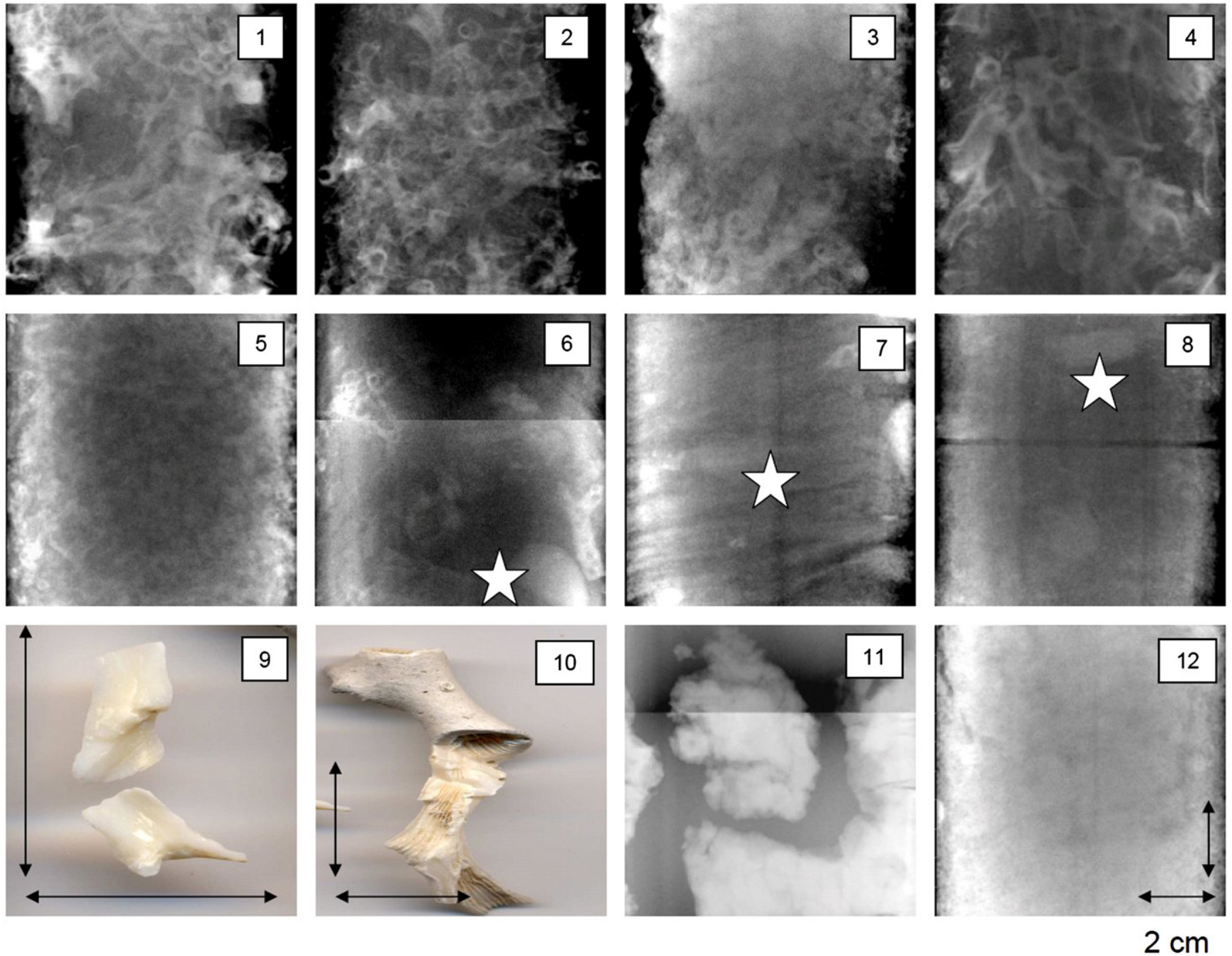

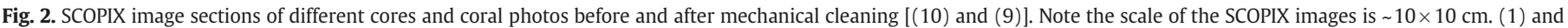

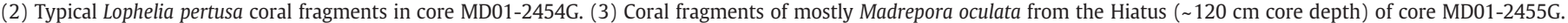

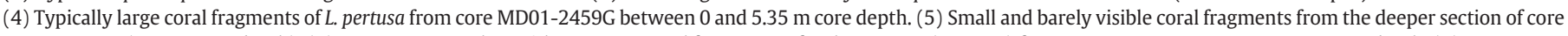

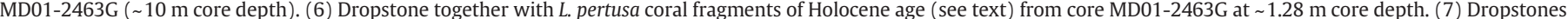

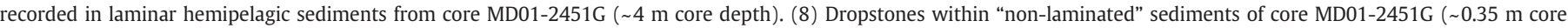

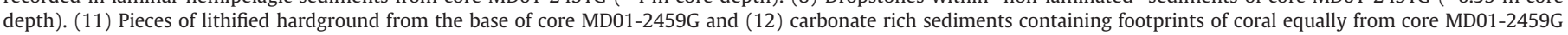
(section below $5.35 \mathrm{~m}$ core depth). 
Table 2

Ages, initial d ${ }^{234} \mathrm{U},{ }^{232} \mathrm{Th}$ concentration and calibrated AMS ${ }^{14} \mathrm{C}$ ages.

\begin{tabular}{|c|c|c|c|c|c|}
\hline Sample-ID & No. & $\begin{array}{l}\text { Depth in core } \\
(\mathrm{cm})\end{array}$ & $\begin{array}{l}\text { Age } \\
\text { (years) }\end{array}$ & $\begin{array}{l}\delta^{23} 4 \mathrm{U} \\
(\%)\end{array}$ & $\begin{array}{l}{ }^{232} \mathrm{Th} \\
(\mathrm{ppb})\end{array}$ \\
\hline \multicolumn{6}{|l|}{ MD01-2454 } \\
\hline MD01-2454 liv P1 & 1 & 0 & $18 \pm 6$ & $144.8 \pm 4.0$ & $0.058 \pm 0.001$ \\
\hline MD01-2454 liv P2 & 2 & 0 & $15 \pm 15$ & $149.1 \pm 3.6$ & $1.202 \pm 0.012$ \\
\hline MD01-2454 Top & 3 & 2 & $360 \pm 140$ & $142.0 \pm 3.0$ & $3.050 \pm 0.031$ \\
\hline MD01 2454G 7-9 cm & 4 & 8 & $891 \pm 89$ & $148.6 \pm 5.3$ & $1.400 \pm 0.016$ \\
\hline MD01 2454G 20-22 cm & 5 & 21 & $1128 \pm 81$ & $142.3 \pm 5.3$ & $2.389 \pm 0.006$ \\
\hline MD01-2454G-31 & 6 & 31 & $1456 \pm 100$ & $145.7 \pm 2.1$ & $3.539 \pm 0.012$ \\
\hline MD01-2454 50-52 cm (14C) & & 51 & $2371 \pm 115$ & \multicolumn{2}{|c|}{ Calibrated ${ }^{14} \mathrm{C}$ age $(R=450 \mathrm{yr})$} \\
\hline MD01-2454G 60-62 cm & 7 & 61 & $2560 \pm 130$ & $148.8 \pm 4.7$ & $0.384 \pm 0.012$ \\
\hline MD01-2454 70-72 cm top (14C) & & 71 & $2463 \pm 110$ & \multicolumn{2}{|c|}{ Calibrated ${ }^{14} \mathrm{C}$ age $(R=450 \mathrm{yr})$} \\
\hline MD01-2454G 85-86c578 & 8 & 85.5 & $3345 \pm 295$ & $155.4 \pm 3.1$ & $7.106 \pm 0.014$ \\
\hline MD01-2454G 85-86c6 & 9 & 85.5 & Rejected & $141.6 \pm 2.3$ & $10.038 \pm 0.020$ \\
\hline MD01-2454G $90 \mathrm{~cm}$ & 10 & 90 & $3190 \pm 240$ & $145.9 \pm 4.3$ & $5.680 \pm 0.011$ \\
\hline MD01 2454G $100 \mathrm{~cm}$ & 11 & 100 & $3523 \pm 91$ & $142.1 \pm 4.0$ & $1.737 \pm 0.005$ \\
\hline MD01 2454G 100 cm dup. & 12 & 100 & $3510 \pm 91$ & $146.2 \pm 2.9$ & $1.737 \pm 0.005$ \\
\hline MD01 2454G 113-117 cm & 13 & 115 & $3600 \pm 130$ & $149.4 \pm 4.6$ & $2.878 \pm 0.012$ \\
\hline MD01-2454G-121 & 14 & 121 & $3831 \pm 27$ & $147.9 \pm 2.2$ & $0.142 \pm 0.001$ \\
\hline MD01 2454G 138-140 cm & 15 & 139 & $4976 \pm 78$ & $143.2 \pm 3.1$ & $0.761 \pm 0.003$ \\
\hline MD01 2454G 138-140 cm dub. & 16 & 139 & $4961 \pm 77$ & $146.2 \pm 2.8$ & $0.761 \pm 0.003$ \\
\hline MD01-2454G 143-145 & 17 & 144 & $4869 \pm 42$ & $153.7 \pm 2.9$ & $0.632 \pm 0.001$ \\
\hline MD01-2454 150 & 18 & 150 & $5040 \pm 61$ & $147.8 \pm 3.1$ & $0.669 \pm 0.001$ \\
\hline MD01-2454G 160-168 cm top & 19 & 164 & $5270 \pm 110$ & $148.8 \pm 2.6$ & $0.276 \pm 0.006$ \\
\hline MD01-2454G 175-180 cm & 20 & 177.5 & $5667 \pm 38$ & $146.5 \pm 2.9$ & $0.360 \pm 0.001$ \\
\hline MD01-2454G $189 \mathrm{~cm}$ & 21 & 189 & $6080 \pm 140$ & $152.6 \pm 3.6$ & $0.534 \pm 0.002$ \\
\hline MD01-2454G 192-194 cm & 22 & 193 & $5620 \pm 240$ & $147.7 \pm 4.8$ & $6.805 \pm 0.011$ \\
\hline MD01-2454G 204-205 cm & 23 & 204.5 & $6992 \pm 214$ & $146.6 \pm 3.5$ & $0.920 \pm 0.022$ \\
\hline MD01-2454G 204-205-1 cm & 24 & 204.5 & $6687 \pm 160$ & $150.6 \pm 3.4$ & $0.856 \pm 0.007$ \\
\hline MD01-2454G 210-217 cm & 25 & 213.5 & $7679 \pm 72$ & $154.1 \pm 4.7$ & $0.833 \pm 0.002$ \\
\hline MD01-2454G $220 \mathrm{~cm}$ & 26 & 220 & $7730 \pm 230$ & $150.7 \pm 4.1$ & $2.741 \pm 0.013$ \\
\hline MD01-2454G 225-227 cm & 27 & 226 & $8430 \pm 200$ & $147.1 \pm 3.9$ & $2.052 \pm 0.007$ \\
\hline MD01-2454G-247 & 28 & 247 & Rejected & $148.0 \pm 2.9$ & $30.15 \pm 0.21$ \\
\hline MD01-2454 273 & 29 & 273 & $9400 \pm 160$ & $148.5 \pm 3.2$ & $3.719 \pm 0.007$ \\
\hline MD01-2454 core cutter 1 & 30 & 275 & $10,880 \pm 340$ & $148.4 \pm 3.3$ & $5.861 \pm 0.018$ \\
\hline MD01-2454 core cutter 2 & 31 & 275 & Rejected & $148.5 \pm 3.5$ & $10.472 \pm 0.043$ \\
\hline \multicolumn{6}{|l|}{ MD01-2459G } \\
\hline MD01-2459G top & 41 & 0 & $4368 \pm 95$ & $151.4 \pm 6.8$ & $0.402 \pm 0.002$ \\
\hline MD01-2459 top II & 42 & 0 & Rejected & $149.1 \pm 3.0$ & $12.761 \pm 0.023$ \\
\hline MD01-2459G 46-53 cm top & 43 & 49.5 & $7540 \pm 180$ & $147.4 \pm 4.1$ & $0.259 \pm 0.001$ \\
\hline MD01-2459G 94-99 cm (14C) & & 96.5 & $8535 \pm 84$ & \multicolumn{2}{|c|}{ Calibrated ${ }^{14} \mathrm{C}$ age $(R=450 \mathrm{yr})$} \\
\hline MD01 2459G 110-114 cm & 44 & 112 & $8765 \pm 190$ & $150.4 \pm 13.8$ & $0.740 \pm 0.002$ \\
\hline MD01-2459G 130-140 cm top (14C) & & 135 & $8604 \pm 96$ & \multicolumn{2}{|c|}{ Calibrated ${ }^{14} \mathrm{C}$ age $(R=450 \mathrm{yr})$} \\
\hline MD01-2459 150 & 45 & 150 & $8520 \pm 100$ & $152.0 \pm 3.1$ & $1.763 \pm 0.003$ \\
\hline MD01-2459G 157-165 cm top (14C) & & 161.5 & $8560 \pm 110$ & \multicolumn{2}{|c|}{ Calibrated ${ }^{14} \mathrm{C}$ age $(R=450 \mathrm{yr})$} \\
\hline MD01 2459G 201-208 cm & 46 & 205 & $8930 \pm 170$ & $148.4 \pm 5.4$ & $0.274 \pm 0.002$ \\
\hline MD01-2459 300 & 47 & 300 & $9290 \pm 210$ & $147.3 \pm 2.4$ & $4.337 \pm 0.006$ \\
\hline MD01-2459 450 & 48 & 450 & $9742 \pm 74$ & $148.1 \pm 3.1$ & $0.080 \pm 0.000$ \\
\hline \multicolumn{6}{|l|}{ MD01-2455G } \\
\hline MD01-2455G top & 50 & 0 & $188 \pm 32$ & $144.0 \pm 11.0$ & $0.600 \pm 0.006$ \\
\hline MD01-2455G 20 & 51 & 20 & $680 \pm 250$ & $150.2 \pm 3.9$ & $6.484 \pm 0.013$ \\
\hline MD01-2455G 45-46 & 52 & 45.5 & $2880 \pm 220$ & $149.2 \pm 5.3$ & $3.866 \pm 0.015$ \\
\hline MD01-2455G 70 & 53 & 70 & $10,670 \pm 460$ & $144.9 \pm 4.4$ & $8.864 \pm 0.017$ \\
\hline MD01-2455G 91 & 54 & 91 & $9370 \pm 220$ & $143.8 \pm 4.6$ & $3.362 \pm 0.005$ \\
\hline MD01-2455G 126-127 & 55 & 126.5 & $11,270 \pm 170$ & $143.6 \pm 3.6$ & $3.568 \pm 0.007$ \\
\hline MD01-2455G 150 & 56 & 150 & $10,270 \pm 320$ & $148.3 \pm 3.1$ & $7.734 \pm 0.015$ \\
\hline MD01-2455G 155-157 & 57 & 156 & $10,660 \pm 230$ & $147.7 \pm 4.0$ & $0.681 \pm 0.002$ \\
\hline MD01-2455G 166-167 & 58 & 168 & $2238 \pm 68$ & $144.3 \pm 3.5$ & $0.647 \pm 0.001$ \\
\hline MD01-2455G 193 & 59 & 193 & $5420 \pm 140$ & $151.0 \pm 6.1$ & $0.133 \pm 0.004$ \\
\hline MD01-2455G cc 1 & 60 & 193 & $7980 \pm 280$ & $149.3 \pm 3.5$ & $3.585 \pm 0.020$ \\
\hline MD01-2455G cc 2 & 61 & 193 & Rejected & $147.2 \pm 2.0$ & $26.28 \pm 0.17$ \\
\hline MD01-2463G & & & & & \\
\hline MD01-2463G top & 70 & 0 & $261 \pm 33$ & $148.1 \pm 9.5$ & $0.800 \pm 0.010$ \\
\hline MD01-2463G $10 \mathrm{~cm}(14 C)$ & & 10 & $851 \pm 99$ & Calibrated ${ }^{14}$ & $0 \mathrm{yr})$ \\
\hline MD01-2463G $100 \mathrm{~cm}(14 C)$ & & 100 & $6811 \pm 88$ & Calibrated ${ }^{14}$ & $0 \mathrm{yr})$ \\
\hline MD01-2463G 139-142 cm & 71 & 140.5 & $9810 \pm 220$ & $154.5 \pm 2.4$ & $3.583 \pm 0.010$ \\
\hline MD01-2463G 144-146 cm & 72 & 145 & Rejected & $143.6 \pm 3.6$ & $24.500 \pm 0.150$ \\
\hline MD01-2463G 178-179 cm & 73 & 178.5 & $9700 \pm 350$ & $154.0 \pm 2.7$ & $9.451 \pm 0.014$ \\
\hline MD01-2463G $300 \mathrm{~cm}$ & 74 & 300 & $247,800 \pm 10,500$ & $153.8 \pm 9.8$ & $6.854 \pm 0.048$ \\
\hline MD01-2451G & & & & & \\
\hline MD01-2451G top & 80 & 0 & Rejected & $151.8 \pm 5.8$ & $21.000 \pm 0.400$ \\
\hline MD01-2451G $6 \mathrm{~cm}$ & 81 & 6 & $3233 \pm 106$ & $145.2 \pm 2.8$ & $0.391 \pm 0.005$ \\
\hline MD01-2451G $27 \mathrm{~cm}$ & 82 & 27 & $6110 \pm 153$ & $147.2 \pm 3.8$ & $0.341 \pm 0.004$ \\
\hline MD01-2451G $31 \mathrm{~cm}$ & 83 & 31 & $6520 \pm 140$ & $154.1 \pm 2.9$ & $1.610 \pm 0.006$ \\
\hline MD01-2451G $223 \mathrm{~cm}$ & 84 & 223 & $78,790 \pm 490$ & $140.3 \pm 2.9$ & $3.791 \pm 0.011$ \\
\hline MD01-2451G $248 \mathrm{~cm}$ & 85 & 248 & $109,200 \pm 773$ & $152.4 \pm 4.4$ & $0.392 \pm 0.009$ \\
\hline MD01-2451G $326 \mathrm{~cm}$ & 86 & 326 & $188,900 \pm 2300$ & $160.7 \pm 4.6$ & $0.595 \pm 0.027$ \\
\hline
\end{tabular}


Table 2 (continued)

\begin{tabular}{|c|c|c|c|c|c|}
\hline Sample-ID & No. & $\begin{array}{l}\text { Depth in core } \\
(\mathrm{cm})\end{array}$ & $\begin{array}{l}\text { Age } \\
\text { (years) }\end{array}$ & $\begin{array}{l}\delta^{23} 4 U \\
(\%)\end{array}$ & $\begin{array}{l}{ }^{232} \mathrm{Th} \\
(\mathrm{ppb})\end{array}$ \\
\hline \multicolumn{6}{|l|}{ MD01-2451G } \\
\hline MD01-2451G 407 cm & 87 & 407 & $230,400 \pm 2900$ & $190.7 \pm 10.0$ & $1.153 \pm 0.005$ \\
\hline MD01-2451G $450 \mathrm{~cm}$ & & 450 & \multirow{3}{*}{\multicolumn{2}{|c|}{$\begin{array}{l}\text { Not datable: activity ratios } \\
\text { equilibrium }\end{array}$}} & $3.791 \pm 0.022$ \\
\hline MD01-2451G $900 \mathrm{~cm}$ & & 900 & & & $5.889 \pm 0.020$ \\
\hline MD01-2451G $1050 \mathrm{~cm}$ & & 1050 & & & $3.401 \pm 0.016$ \\
\hline
\end{tabular}

Radiocarbon ages are indicated with bold-italic in contrast to U-series age and isotope data.

and Madrepora oculata varies strongly between $\sim 2.80$ and $\sim 5.0 \mu \mathrm{g}$ $\mathrm{g}^{-1}$. Initial $\delta^{234} \mathrm{U}_{0}$ values range between $140 \%$ and $155 \%$ owith a mean of $148 \pm 3.5 \%$ o $(n=63$; standard deviation $= \pm 2 \sigma)$ identical to measured present day seawater values of 146.6-149.6\% (Delanghe et al., 2002; Robinson et al., 2004). Measured ${ }^{232}$ Th concentrations are small $\left(<10 \mathrm{ng} \mathrm{g}^{-1}\right)$ for most samples. In cases were ${ }^{232} \mathrm{Th}$ exceeded values of $10 \mathrm{ng} \mathrm{g}^{-1}$, data was rejected $(n=7)$ to avoid propagating large uncertainties into the age estimate derived from correction models. Small amounts of ${ }^{232} \mathrm{Th}$ and ${ }^{230} \mathrm{Th}$ from detritus and from seawater may affect however the ${ }^{230} \mathrm{Th} / \mathrm{U}$ age. Consequently a correction model considering precipitation of ${ }^{230} \mathrm{Th}$ from seawater was applied taking seawater $\left({ }^{232} \mathrm{Th} /{ }^{230} \mathrm{Th}\right)$ activity ratios ranging from 14 to 6 into account (Frank et al., 2004). The uncertainty of this correction was propagated into the age uncertainty, resulting in a slight decrease of ages (within uncertainty of the mean age) but a significant increase of age errors as a consequence of error propagation (Table 2 ).

U-series ages from the upper most coral rich section of all investigated sites range from 0 to $12 \mathrm{ka}$. Solely a few ages from the second coral rich units are presented for core $63 \mathrm{G}$ and $51 \mathrm{G}$ to identify the age difference between the recent coral growth and last coral occurrence prior to this interval. The section underneath the recent coral development recorded in core $63 \mathrm{G}$ dates back to $240 \mathrm{ka}$, while the one of core $51 \mathrm{G}$ dates back to $\sim 80$ to $110 \mathrm{ka}$ (Table 2). Consequently, on those two sites corals of Holocene age developed on ancient reef surfaces that remained from marine isotope stage 7 and 5.

\subsection{Mound evolution during the Holocene}

The most detailed Holocene record is established in gravity core 54G from Rockall Bank showing almost continuous but irregular growth of mainly Lophelia pertusa corals over the past $11 \mathrm{ka}$ until present (Fig. 3). Coral fragments have been recovered on top of a hard-substrate (lithified carbonate) consequently corals of preHolocene origin were not recovered. Based on the relationship of coral ages and depth in the core we can estimate VMGRs. In core $54 G$ VMGRs are highly variable and rang from $<15 \mathrm{~cm} \mathrm{ka}^{-1}$ to $>70 \mathrm{~cm} \mathrm{ka}^{-1}$ (Fig. 3a). The initial start of the reef after the Younger Dryas cold reversal (12.9-11.5 ka calibrated BP) is followed by a period of rapid mound growth between 9.5 and $8.5 \mathrm{ka}\left(\sim 60 \mathrm{~cm} \mathrm{ka}^{-1}\right)$, which is unfortunately poorly dated so far (Fig. 3a). Next, VMGR is 4 times lower $\left(\sim 15 \mathrm{~cm} \mathrm{ka}^{-1}\right)$ until 6 ka followed again by a period of more rapid coral fragment accumulation from 6 to $5 \mathrm{ka}$. The VMGR is close to zero or at least strongly reduced thereafter at $4.4 \pm 0.4 \mathrm{ka}$, $2.9 \pm 0.1 \mathrm{ka}$, and at $1.9 \pm 0.3 \mathrm{ka}$. In between those intervals of almost absent coral fragment deposition, VMGR are high (40 to $70 \mathrm{~cm} \mathrm{ka}^{-1}$ ). Finally during the past $1.5 \mathrm{ka}$ the reef evolves again at a rate of $\sim 30 \mathrm{~cm}$ $\mathrm{ka}^{-1}$ (Fig. 3a).

Core $55 \mathrm{G}$ located in close vicinity of core $54 \mathrm{G}$ but at shallower depth of $640 \mathrm{~m}$ reveals similar coral ages, but a strongly disturbed age-depth relationship (Fig. 3b). Note that the core is composed of mainly Madrepora oculata fragments, a species which construct a thinner and likely more unstable open framework. The dominant age reversal recorded between 70 and $156 \mathrm{~cm}$ core depth demonstrates clearly coral debris redistribution likely through physical erosion. This layer corresponds to a core section filled mainly with "coral rubble" (small broken fragments barely visible in the X-ray images) (Fig. 2 [3]). Corals in this section are about $9.4 \mathrm{ka}$ to $11 \mathrm{ka}$ old and are thus of equal ages compared to corals obtained at the base of core 54G. Consequently, we may assume that the $M$. oculata reef started to develop on top of exposed hardgrounds about $11 \mathrm{ka}$ ago as did the Lophelia pertusa reef at deeper water depth (core 54G). During the Holocene, corals have than been displaced as a consequence of physical mound erosion. Below this section corals seem in chronological order and the few fragments dated reveal ages between 8 and $3 \mathrm{ka}$, but the resulting VMGRs are $<5 \mathrm{~cm} \mathrm{ka}^{-1}$. On top of the hiatus corals are again in chronological order with one age at $\sim 2.88 \mathrm{ka}$ and several between 1 and $0.2 \mathrm{ka}$. The resulting VMGR is approximately $30 \mathrm{~cm} \mathrm{ka}^{-1}$, thus similar to the one observed for the topmost $50 \mathrm{~cm}$ in nearby core 54G. Therefore, during the past $1 \mathrm{ka}$ corals did well develop on both sites until present.

Within Porcupine Seabight coral rich sediment sequences underneath the most recent coral growth interval have been recovered, with the exception of core 59G situated in the Magellan Mound Province. Within this last core 59G from Mound Perseverance corals appear ones more on top of a lithified carbonate layer at $5.35 \mathrm{~m}$ core depth about 9.7 ka to $10 \mathrm{ka}$ ago (Fig. 3c). Vertical mound growth is continuous but irregular again between $10 \mathrm{ka}$ and $4.3 \mathrm{ka}$, with a high VMGR of up to $220 \mathrm{~cm} \mathrm{ka}^{-1}$ between $9.8 \mathrm{ka}$ and $8.5 \mathrm{ka}$, followed by a lower VMGR of $\sim 25 \mathrm{~cm} \mathrm{ka}^{-1}$ between $8 \mathrm{ka}$ and $4.3 \mathrm{ka}$ (Fig. 3c), respectively. Today, this mound is known to have an actively growing but patchy coral reef ecosystem (Olu Le-Roy and Shipboard Scientific Crew, 2002) and therefore the mid-Holocene end of coral growth recorded here does not reflect a shut down of coral growth lasting for $4.3 \mathrm{ka}$. This sudden stop of local mound evolution is a result of missing accessibility (loss of the top sediment during coring), reef erosion through deep trawling as found on some mounds of the Magellan Mound province (Fossa et al., 2003), or a collapse of the recent coral framework such as observed in sediment core 55G from Rockall Bank. In this case corals are lost rather than re-deposited. Thus, we observe a similar timing for the start of the coral ecosystems on SW Rockall Bank and within the Magellan Mound Province in Porcupine Seabight. The reefs develop quickly between 9.5 and $8 \mathrm{ka}$ and then between 8 and $4.3 \mathrm{ka}$ the local reef activity declined.

In the southern Porcupine Seabight corals have been recovered from Thérèse Mound (core 63G) and from Challenger Mound (core 51G) both within the Belgica Mound Province. The upper most core sections again reflect Holocene coral development, but the temporal resolution obtained here is very limited and the respective core sections are small; $120 \mathrm{~cm}$ depth in core $63 \mathrm{G}$ and solely $32 \mathrm{~cm}$ depth in core 51G (Fig. 3d and e). In core 63G corals build their framework on top of an exposed ancient reef that dates back to some $250 \mathrm{ka}$ (Table 2). But coral ages are around $10 \mathrm{ka}$ (Fig. 3) just on top of the ancient reef. Hence, ones more the timing of corals is similar to the one within the Magellan Mound Province and the one in SW Rockall Bank. The first appearance of corals in core 63G is intersected with remains of glacial sedimentation containing a dropstone (between $160 \mathrm{~cm}$ and $178 \mathrm{~cm}$ depth), resulting from early Holocene iceberg discharge along the Irish margin. Whether the growth of corals was then continuous or irregular cannot be decided from the scares ages. VMGR from $10 \mathrm{ka}$ to present amounts to $\sim 15 \mathrm{~cm} \mathrm{ka}^{-1}$ and is thus on the lower end of those observed on the other mounds. Thérèse Mound 


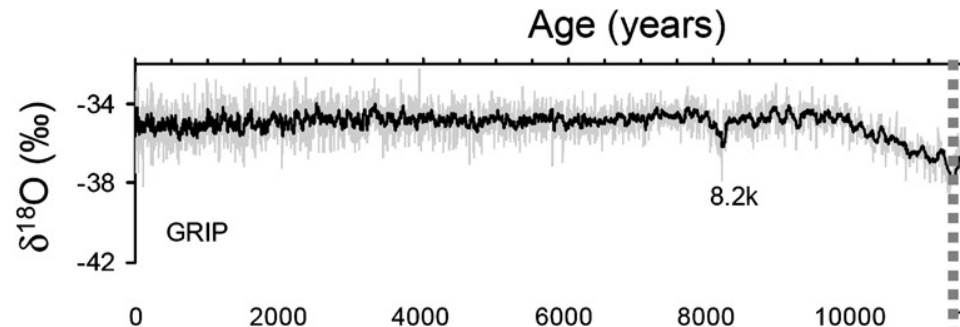

Younger

Dryas
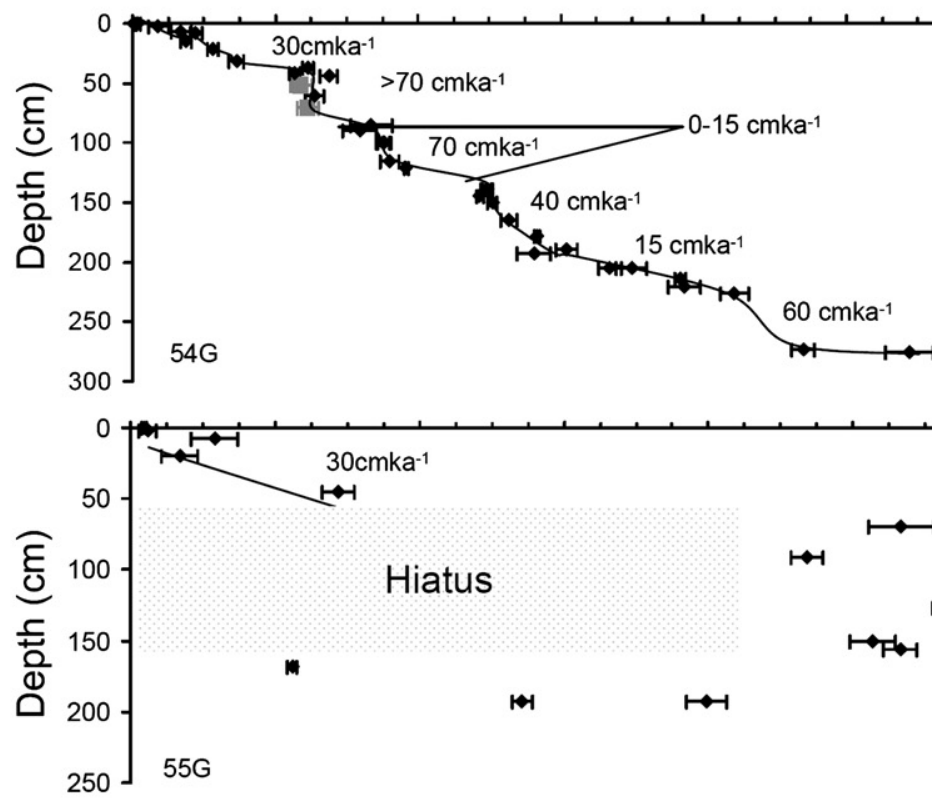

b

a

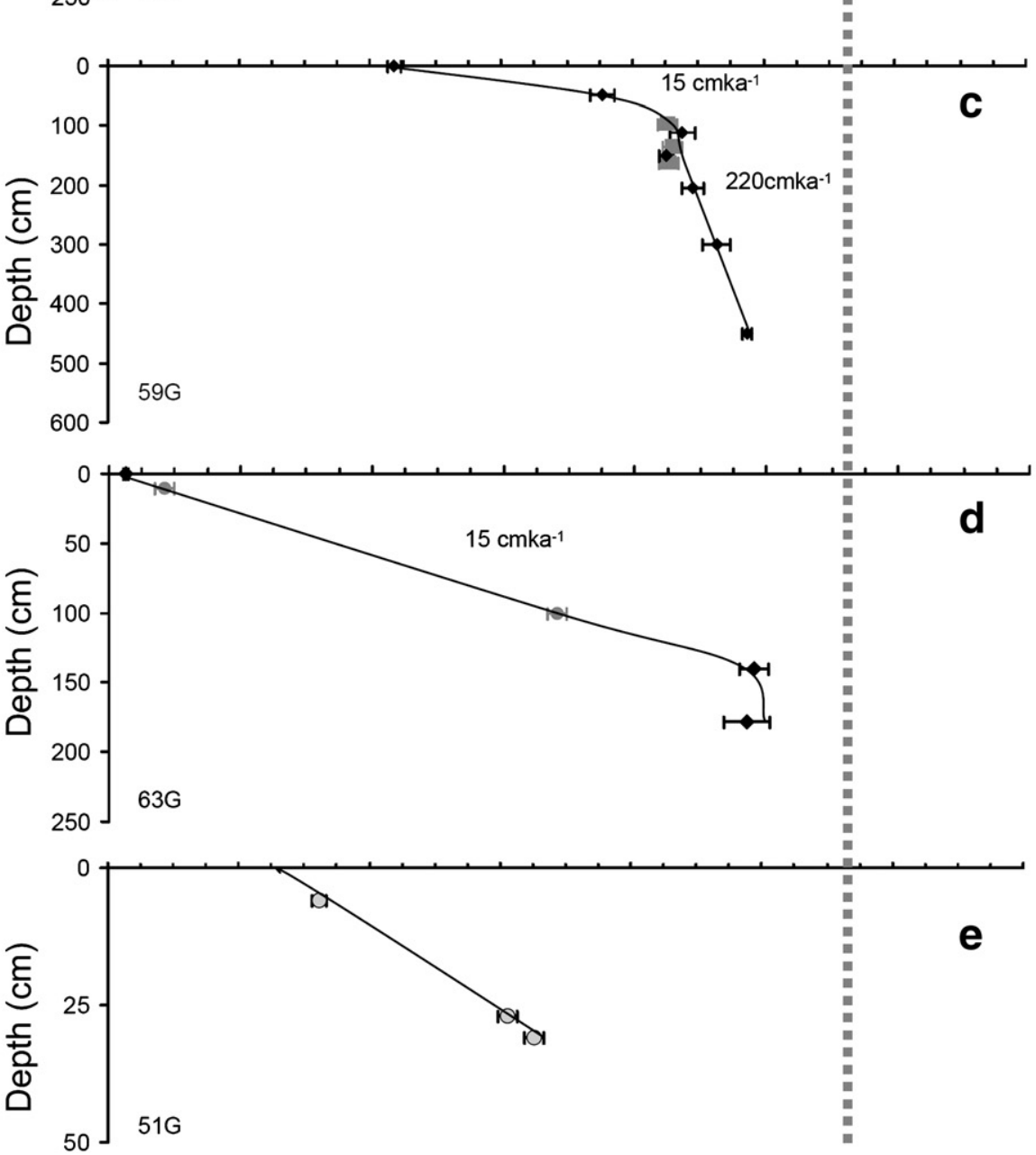


is known for its presently active Lophelia pertusa and Madrepora oculata coral ecosystem, which reaches from the south-western flank to the top with dense coral populations (Olu Le-Roy, 2004). Consequently at $880 \mathrm{~m}$ water depth coral growth conditions have been favourable for the past $10 \mathrm{ka}$, but whether or not certain time intervals are more or less important can yet not be resolved. Challenger Mound (core 51G) situated a few hundred meters higher in the water column also shows Holocene coral development, but throughout a very small sedimentary interval of solely $32 \mathrm{~cm}$. Ages progressively increase from $31 \mathrm{~cm}$ to the top. Corals appear around $6.3 \mathrm{ka}$ on the sampled location and thus by far later than at the other investigated Mounds (Fig. 3e). In addition, the VMGR derived from the coral age-depth relationship is solely $\sim 8 \mathrm{~cm} \mathrm{ka}^{-1}$ and corals "disappeared" on the investigated spot most likely about 3000 years ago as today Challenger Mound is covered entirely with dead coral rubble (Williams et al., 2006). Interestingly, corals appear directly on glacial sediments containing ice rafted debris and thus a hard-substrate is missing, which certainly did not favour coral settlement. Corals situated within the second coral fragment rich sediment section between 220 and $250 \mathrm{~cm}$ depth date back to marine isotope 5 (Table 2 ).

\section{Discussion}

Lophelia pertusa and Madrepora oculata corals build their open framework with high individual and colony growth rates of tens of millimeters per year (meters per ka) (Mikkelsen et al., 1982; Freiwald et al., 1997; Mortensen and Rapp, 1998; Gass and Roberts, 2006). This framework acts as sediment trap for horizontal and lateral sediment fluxes. Overall rates of mound growth are much lower than the ones of the open framework construction (de Haas et al., 2009), but largely outpace background sedimentation (de Haas et al., 2009; de Mol et al., 2002). Dating of coral fragments has revealed that the past $11 \mathrm{ka}$ are in general favorable for coral growth. Older coral reef growth episodes occurred during previous climate warm stages such as marine isotope stage 5 and 7 (Rüggeberg et al., 2003; Dorschel et al., 2005; Frank et al., 2005; Kano et al., 2007; Rüggeberg et al., 2007; Eisele et al., 2008; Mienis et al., 2009) (Table 2). Mound records are thus often discontinuous in particular between coral growth intervals and in many cases glacial sedimentation is missing or almost absent (Rüggeberg et al., 2003; Dorschel et al., 2005; Frank et al., 2005; Kano et al., 2007; Rüggeberg et al., 2007; Eisele et al., 2008; Mienis et al., 2009). Yet, no corals of glacial environments have been discovered on and off mounds in Porcupine Seabight and on SW Rockall Bank (Rüggeberg et al., 2003; Schröder-Ritzrau et al., 2005; Dorschel et al., 2005; Frank et al., 2005; Kano et al., 2007; Rüggeberg et al., 2007; Eisele et al., 2008; Mienis et al., 2009). Our results largely reinforce the scares previous observations but we further achieved a time resolution allowing the study of secular variations of coral growth on mounds during the most recent period of mound development: the Holocene.

Northern Hemisphere warming during the early Holocene and the establishment of similar to modern hydrological conditions in the near thermocline waters are accompanied by an increase in surface productivity and a retreat of the polar fronts towards more northern locations. Consequently, productivity increases as recorded by a 3 to 4 fold increase in planktonic foraminifera abundance and $\mathrm{CaCO}_{3}$ content of sediments from the Faeroe Margin following directly on the Younger Dyras cold reversal (Abrantes et al., 1998) and reduced terrigeneous sediment fluxes (Manighetti and McCave, 1995). Following upon the Younger Dryas cold reversal at about 11 ka corals re-appear on mounds of Porcupine Seabight and on mounds of SW
Rockall Bank and likely also further to the North synchronous to environmental changes recorded in sediments. Over the course of the Holocene, productivity is then unlikely to change in a dramatic way, and millennium scale oceanographic changes (Bond et al., 2001) are unlikely to alter dramatically the local hydrodynamic regime near mounds driven by strong bottom water currents and tidal waves (White et al., 2005; Dorschel et al., 2007; Mienis et al., 2007). Moreover, deep-water corals develop today over a large range of environmental conditions from the Mediterranean Sea to the northern margin of the Norwegian shelf.

The temporal variability of the local VMGR is the product of coral open framework construction-skeleton degradation-bioerosion-sediment trapping and compaction. Thus, VMGRs are related to coral population density through time. Low coral growth activity will provide numerous exposed sediment surfaces that are subject to erosion in an environment of high bottom water currents, while densely populated reefs produce more degraded coral fragments on the seafloor that cover the sediment surfaces and which will pile up on top of each other. Furthermore, a well developing open coral framework will more efficiently trap sediment. Hence, we therefore interpret VMGRs as representative of densely populated reefs, while low rates or absent coral ages are likely indicative of reduced coral activity and mound erosion.

All sites reflect a local environment, but we can test whether the overall coral age pattern of all investigated mounds is similar and whether changes of the local VMGRs add evidence to such a regional time framework. Fig. 4 presents all U-series ages for SW Rockall Bank and Porcupine Seabight including a few previously published ages for both regions (Schröder-Ritzrau et al., 2005; Eisele et al., 2008; Mienis et al., 2009). A total 88 ages are presented. Core 54G from SW Rockall Bank $(n=36)$ dominates the age pattern and clearly marks out numerous periods of missing coral ages at $0.6 \mathrm{ka}, 1.8-2.0 \mathrm{ka}, 4.2-$ $4.8 \mathrm{ka}$ (Fig. 3a), which we interpreted as reduced local reef activity. Moreover VMGR is reduced between $6-8 \mathrm{ka}$ (Fig. 3a). The age pattern is biased in particular at the base of the core $54 \mathrm{G}$ in which a high VMGR was observed between 9 to 8 ka based on solely two ages (Fig. 3a). Ages from all other investigated sites, add further evidence to the temporal pattern of coral ages of core 54G. Note that this pattern cannot be biased by the sampling strategy as corals have been selected with depth in the cores first and than sampling continued to fill in the time gaps, which finally revealed the absence of corals at certain time laps. The statistical significance of Fig. 4 is obviously weak, with 88 ages out of several hundred coral fragments. However, ages and VMGRs point towards potential synchronous changes of coral population density on all investigated mounds at 1.8-2.0 ka, 4.2$4.8 \mathrm{ka}$ (Fig. 4). At $8.2 \mathrm{ka}$ there is also a pronounced abundance change followed by a period of reduced VMGR until 6 ka (Figs. 3, 4).

Please note that corals are unlikely to disappear, we suggest that population density decreases. This is puzzling, specifically the abundance change at $8.2 \mathrm{ka}$, an event not yet resolved in the coral age-depth plots. This may be an artifact or in fact represent a crucial moment of changing environmental conditions at thermocline depth triggered by a short "cold" climate excursion in northern Europe around 8.175 ka ago (Kobashia et al., 2007) of less than $0.15 \mathrm{ka}$ duration. The observed lack of coral ages at 1.8-2.0 and 4.2-4.8 ka is even more puzzling together with the observation of high VMGR before and after those times. The Holocene is marked by millennium climate variability, but no records of productivity or current activity exist that may provide a clear hind on changes of corals environmental growth conditions. However periods lacking corals reflect warm climate conditions in the northern Hemisphere, while those having

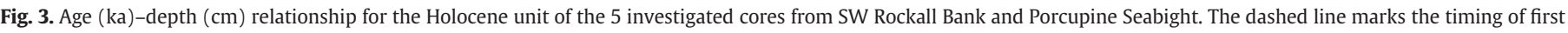

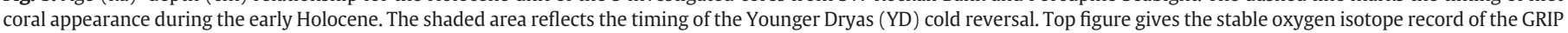
ice core. Mound accumulation rates are shown in $\mathrm{cm} \mathrm{ka}^{-1}$. 
$\circ 54 G \triangle 51 G \circ 55 G \triangle 59 G \cdot$ ENAM $\bullet$ Schroeder-R et al. $\circ$ Minies et al. $\triangle$ Eisele et al.

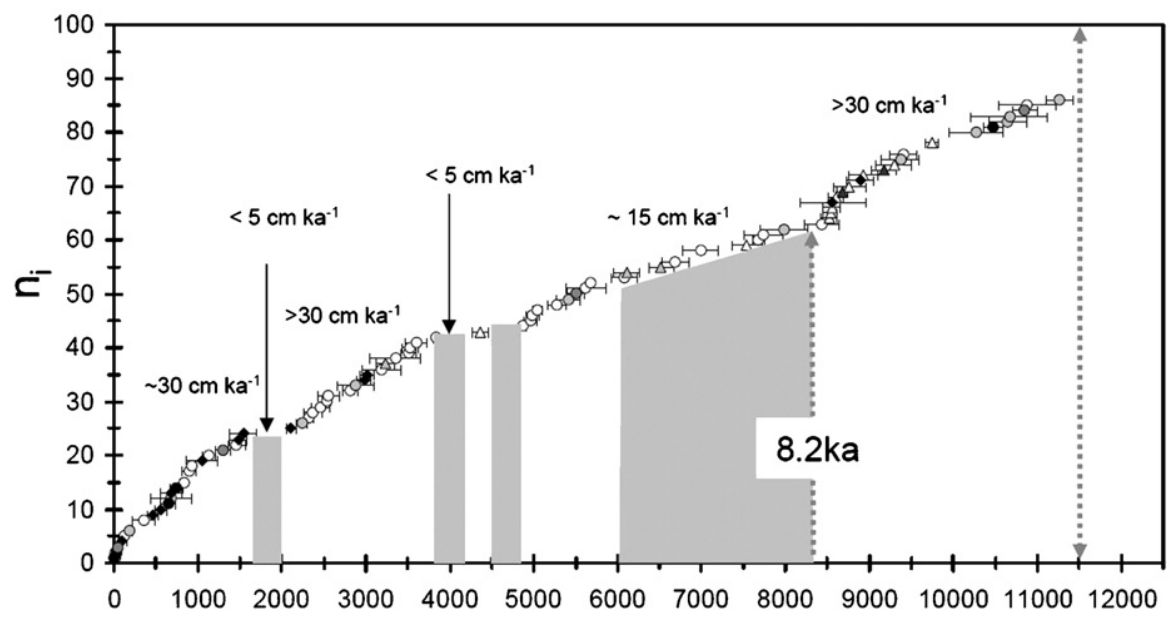

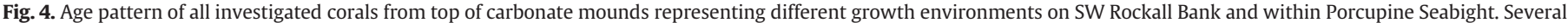
ages obtained during previous studies are included (see text).

high VMGR reflect colder climate conditions as recorded in marine and continental records (Bond et al., 2001; Vollweiler et al., 2006; Mangini et al., 2007). Moreover, periods without corals coincide with increased freshwater discharge of European rivers (Benito et al., 2008). While, glacial environmental conditions apparently inhibit reef development potentially through the absence of sufficient food or reduced bottom current activity and enhanced sedimentation, one may speculate whether particular warm periods seem to decrease coral populations as well. In this case, food supply and current dynamic is unlikely the reason as productivity and northward water mass transport is supposedly rather high during the entire Holocene compared to "cold" boundary conditions. Hence, one may speculate whether changes in vertical mixing affect the nutrient availability, or whether background sedimentation increased hindering corals to effectively filter food. Recently, Dullo et al. (2008) have shown that active coral reefs are situated on the Celtic margin and within the Norwegian Sea at a particular water density envelope of sigma-theta $\left(\sigma_{\Theta}\right)=27.35$ to $27.65 \mathrm{~kg} \mathrm{~m}^{-3}$. Changes of the density structure at upper intermediate depth through time may cause reduced coral reproduction and thus coral reefs may decline. Thornalley et al. (2009) just revealed first evidence of changes of South Iceland density structures for the sub-surface ocean during the Holocene, suspected to be primarily related to changes in the exchange of subpolar and subtropical gyre waters. Times of reduced coral activity at 1.8-2.0 ka and between 6 and 8 ka do correspond to periods of similar surface and sub-surface densities contrasting periods of significantly different salinity values (Thornalley et al., 2009). However, for the period between 4.2 and $4.8 \mathrm{ka}$ this correlation is not well evident. Upper intermediate depth water masses at Rockall Bank are well situated at the interface of both gyres today, but water masses at Porcupine Seabight are in addition influenced by MOW. Assuming a link between South Iceland density variations and coral activity on Rockall Bank slopes, we would further expect decreasing coral activity at around 3.2 and $0.9 \mathrm{ka}$, which is apparently the case in core 54G from SW Rockall Bank (Fig. 3a). Consequently, the density structure of the North Atlantic may in fact play a role in modulating reef activity throughout the Holocene, but it is unlikely the only mechanism. By far more chronological data and information on the dominant biological limits are needed to better constrain these first observations of reduced coral activity throughout Holocene warm phases. But, if those climate related patterns truly exist we need to elucidate the processes causing the decline and growth of corals on mounds as future global warming and ocean acidification imposes an important threat on the survival of such ecosystems.

\section{Conclusion}

U-series dating of constructional deep-water corals taken on top of carbonate mounds are powerful tools to reconstruct the temporal evolution of such ecosystems of the deep ocean. We have presented first evidence of climate driven changes of coral abundance on mounds during the present climate warm stage. Coral growth on SW Rockall Bank and within Porcupine Seabight occurs early in the Holocene almost simultaneously on several mounds and corals develop prosperously thereafter. Active reef growth result in vertical mound growth rates of $>15 \mathrm{~cm} \mathrm{ka}^{-1}$, but local VMGRs can exceed $200 \mathrm{~cm} \mathrm{ka}{ }^{-1}$. Over the past $11 \mathrm{ka}$ we have found first evidence of temporal changes in reef activity as coral abundances and mound growth rates decline to less than $10 \mathrm{~cm} \mathrm{ka}^{-1}$ at $1.8-2.0 \mathrm{ka}, 4.2-4.8 \mathrm{ka}$ and 6-8 ka. Moreover, the onset of the decline of corals activity coincides with a cold climate reversal at $8.2 \mathrm{ka}$.

In addition, we have confirmed that periods favourable for coral growth on SW Rockall Bank and in Porcupine Seabight are related to overall climatic warm phases (MIS 1, 5, 7) and that coral growth is largely reduced or even absent "on mounds" during cold phases such as glacial periods and even MIS 3. Thus, coral growth records follow a glacial/interglacial pattern and are discontinuous in time and space. Detailed chronological studies, however, provide first evidence that those ecosystems are sensitive to even small changes of environmental conditions such as productivity, current activity and potentially water mass density affected by climate change. Finally, the reconstruction of mound evolution during the past 11 ka provides further constrains on mound evolution on geological time scales as it clearly highlights the strong variability of the vertical mound growth rates on solely a few thousand years and on less than a few cm core depth.

\section{Acknowledgements}

This work was funded through the European Union (projects: ECOMOUND, GEOMOUND, and HERMES: EVK3-CT-1999-00013, 00016 and GOCE-CT-2005-511234-1) and by the French Centre National de la Recherche Scientifique (CNRS) and the Commisariat à l'Energie Atomique (CEA). We thank IPEV (Institut Polaire Emile Victor), the members and crew of GEOMOUND Marion Dufresne cruise, for their excellent work recovering these unique sediment cores and deep-water corals presented here. David van Rooij is a postdoctoral fellow of the FWO Flanders. O. Weber, M. Cremer and S. Saint-Paul (DGO, University Bordeaux) are acknowledged for their support with the SCOPIX analyses. Thanks to the constructive 
comments and critical questions of Augusto Mangini, Christine Hatté and an anonymous reviewer this manuscript has greatly improved. Furthermore, the work is part of the ESF Eurodiversity project MiCROSYSTEMS.

\section{References}

Abrantes, F., et al., 1998. Sediment fluxes along the northeastern European Margin: inferring hydrological changes between 20 and 8 kyr. Marine Geology 152, 7-23.

Adkins, J.F., Cheng, H., Boyle, E.A., Druffel, E.R.M., Edwards, R.L., 1998. Deep-sea coral evidence for rapid change in ventilation of the deep North Atlantic 15,400 years ago. Science 280, 725-728.

Benito, G., Thorndycraft, V.R., Rico, M., Sánchez-Moya, Y., Sopeña, A., 2008. Palaeoflood and floodplain records from Spain: evidence for long-term climate variability and environmental changes. Geomorphology 101, 68-77.

Bond, G., et al., 2001. Persistent solar influence on North Atlantic climate during the Holocene. Science 294 (2130-2136).

Cheng, H., Adkins, J.F., Edwards, R.L., Boyle, E.A., 2000a. U-Th dating of deep-sea corals. Geochimica et Cosmochimica Acta 64, 2401-2416.

Cheng, H., et al., 2000b. The half-lives of uranium-234 and thorium-230. Chemical Geology 169, 17-33.

de Haas, H., et al., 2009. Morphology and sedimentology of (clustered) cold water cora mounds at the south Rockall Trough margins, NE Atlantic Ocean. Facies 55, 1-26.

de Mol, B., et al., 2002. Large deep-water coral banks in the Porcupine Basin southeast of Ireland. Marine Geology 188, 193-231.

de Mol, B., et al., 2007. Thérèse Mound: a case study of coral bank development in the Belgica Mound Province, Porcupine Seabight. International Journal of Earth Science 96, 103-120.

Delanghe, D., Bard, E., Hamelin, B., 2002. New TIMS constraints on the uranium-238 and uranium-234 in seawaters from the main ocean basins and the Mediterranean Sea. Marine Chemistry 80, 79-93.

Dorschel, B., Hebbeln, D., Rüggeberg, A., Dullo, W.-C., Freiwald, A., 2005. Growth and erosion of a cold-water coral covered carbonate mound in the Northeast Atlantic during the Late Pleistocene and Holocene. Earth and Planetary Science Letters 233, 33-44.

Dorschel, B., Hebbeln, D., Foubert, A., White, M., Wheeler, A.J., 2007. Hydrodynamics and cold-water coral facies distribution related to recent sedimentary processes at Galway Mound west of Ireland. Marine Geology 244, 184-195.

Dullo, W.-C., Flögel, S., Rüggeberg, A., 2008. Cold-water coral growth in relation to the hydrography of the Celtic and Nordic European Continental Margin. Marine Ecology Progress Series 371, 165-176.

Eisele, M., Hebbeln, D., Wienberg, C., 2008. Growth history of a cold-water coralcovered carbonate mound - Galway Mound, Porcupine Seabight, NE Atlantic. Marine Geology 253, 160-169.

Ellett, D.J., Martin, J.H.A., 1973. The physical and chemical oceanography of the Rockal Channel. Deep-Sea Research 20, 585-625.

Fossa, H., et al., 2003. Report of the Study Group on Cold-Water Corals. Internationa Council for the exploration of the Sea, Copenhagen.

Foubert, A., et al., 2005. New view of the Belgica Mounds, Porcupine Seabight, NE Atlantic: preliminary results from the Polarstern ARK-XIX/3a ROV cruise. In: Freiwald, A., Roberts, J.M. (Eds.), Cold-Water Corals and Ecosystems. SpringerVerlag, Berlin, pp. 403-415.

Foubert, A., van Rooij, D., Blamart, D., Henriet, J.P., 2007. X-ray imagery and physical core logging as a proxy of the content of sediment cores in cold-water coral moun provinces: a case study from Porcupine Seabight, SW of Ireland. International Journal of the Earth Sciences 96, 141-158.

Frank, N., et al., 2004. Eastern North Atlantic deep-sea corals: tracing upper intermediate water Delta14C during the Holocene. Earth and Planetary Science Letters 219, 297-309.

Frank, N., et al., 2005. Cold water corals of the northeastern Atlantic margin: carbonate mound evolution and upper intermediate water ventilation during the Holocene. In: Freiwald, A. (Ed.), Springer Special Publication. Springer, Berlin, Heidelberg.

Freiwald, A., Roberts, J.M., 2005. Cold-water corals and ecosystems, 1. Springer, Heidelberg. 1243 pp.

Freiwald, A., Henrich, R., Pätzold, J., 1997. Anatomy of a deep-water coral reef mound from Stjernsund West Finnmark, northern Norway. SEPM Special Publications 56 141-162.

Gass, S.E., Roberts, J.M., 2006. The occurrence of the cold water coral Lophelia pertusa (Scleractinia) on oil and gas platforms in the North Seas: colony growth, recruitment and environmental controls on distribution. Marine Pollution Bulletin 52, 549-559.

Henriet, J.P., et al., 1998. Gas hydrate crystals may help build reefs. Nature 391, 648-649.

Holliday, N.P., Pollard, R.T., Read, J.F., Leach, H., 2000. Water mass properties and fluxes in the Rockall Trough 1975-1998. Deep-Sea Research I (47), 1303-1332.

Hovland, M., Croker, P.F., Martin, M., 1994. Fault-associated seabed mounds (carbonate knolls?) off western Ireland and north-west Australia. Marine and Petroleum Geology 11 (2), 232-246.

Hovland, M., Mortensen, P.B., Brattegard, T., Strass, P., Rokoengen, K., 1998. Ahermatypic coral banks off mid-Norway: evidence for a link with seepage of light hydrocarbons. Palaios 13, 189-200.

Huthnance, J.M., 1986. The Rockall Slope Current and shelf edge processes. Proceeding of the Royal Society of Edinburgh 88 B, 83-101.
Huvenne, V., de Mol, B., Henriet, J.P., 2003. A 3D seismic study of the morphology and spatial distribution of buried coral banks in the Porcupine Basin, SW of Ireland. Marine Geology 198, 5-25.

Huvenne, V.A.I., et al., 2005. The seabed appearance of different coral bank provinces in the Porcupine Seabight, NE Atlantic: results from sidescan sonar and ROV seabed mapping. In: Freiwald, A., Roberts, J.M. (Eds.), Cold Water Corals and Ecosystems. Springer Verlag, Berlin Heidelberg, pp. 535-569.

Huvenne, V.A.I., et al., 2007. The Magellan mound province in the Porcupine Basin. International Journal of Earth Sciences 96, 85-101.

Kano, A., et al., 2007. Age constraints on the origin and growth history of a deep-water coral mound in the northeast Atlantic drilling during integrated Ocean Drilling Program Expedition 307. Geology 35 (11), 1051-1054.

Kenyon, N.H., et al., 2003. Giant carbonate mud mounds in the southern Rockall Trough. Marine Geology 195, 5-30.

Kobashia, T., Severinghausa, J.P., Brookb, E.J., Barnolac, J.-M., Gracheva, A.M., 2007. Precise timing and characterization of abrupt climate change 8200 years ago from air trapped in polar ice. Quaternary Science Reviews 26, 1212-1222.

Lomitschka, M., Mangini, A., 1999. Precise Th/U-dating of small and heavily coated samples of deep sea corals. Earth and Planetary Science Letters 170, 391-401.

Mangini, A., et al., 1998. Coral provides way to age deep water. Nature 392, 347.

Mangini, A., et al., 2007. Persistent influence of the North Atlantic hydrography on central European winter temperature during the last 9000 years. Geophysical Research Letters 34, L02704. doi: 10.1029/2006GL028600.

Manighetti, B., McCave, I.N., 1995. Late glacial and Holocene paleocurrents around Rockall Bank, NE Atlantic Ocean. Paleoceanography 10 (3), 611-626.

Mienis, F., et al., 2007. Hydrodynamic controls on cold-water coral growth and carbonate-mound development at the SW and SE Rockall Trough Margin, NE Atlantic Ocean. Deep-Sea Research I (54), 1655-1674.

Mienis, F., et al., 2009. Carbonate accumulation on a cold water carbonate mound at southwest Rockall Trough margin. Marine Geology 265, 40-50.

Mikkelsen, N., Erlenkeuser, H., Killingley, J.S., Berger, W.H., 1982. Norwegian corals: radiocarbon and stable isotopes in Lophelia pertusa. Boreas 11, 163-171.

Mortensen, P., Rapp, H.T., 1998. Oxgyen and carbon isotope ratios related to growth line patterns in skeletons of Lophelia pertusa (L. pertusa) (Anthozoa, Scleractinia): implications for determination of linear extension rates. Sarsia 83, 433-466.

New, A.L., Smythe-Wright, D., 2001. Aspects of the circulation in the Rockall Trough. Continental Shelf Research 21, 777-810.

Olu Le-Roy, K., 2004. Les coraux profonds: une biodiversité à évaluer et à préserver. VERTIGO Revue Electronique en Environnement 5.

Olu Le-Roy, K., Shipboard Scientific Crew, 2002. NO ‘Atalante’ and ROV ‘Victor 6000’ 2. IFREMER, Brest

Roberts, M., Wheeler, A.J., Freiwald, A., 2006. Reefs of the deep: the biology and geology of deep-water coral ecosystems. Science 312, 543-547.

Robinson, L.F., Belshaw, N.S., Henderson, G.M., 2004. U and Th concentrations and isotope ratios in modern carbonates and waters from the Bahamas. Geochimica et Cosmochimica Acta 68 (8), 1777-1789.

Roberts, J.M., Wheeler, A.J., Freiwald, A., Cairns, S. (Eds.), 2009. Cold-Water Corals: The Biology And Geology Of Deep-Sea Coral Habitats. Cambridge University Press, Cambridge. 334 pp.

Rüggeberg, A., Dorschel, B., Dullo, W.-C., Hebbeln, D, 2003. Environmental control on Propeller Mound (Hovland Mound Province) during the past interglacial-glacial Cycles. In: Freiwald, A., Schulbert, C. (Eds.), 2nd International Symposium on DeepWater Corals. Erlanger geologische Abhandlungen, Erlangen, Germany, p. 109

Rüggeberg, A., Dullo, C., Dorschel, B., Hebbeln, D., 2007. Environmental changes and growth history of Propeller Mound, Porcupine Seabight: evidence from benthic foraminiferal assemblages. International Journal of Earth Sciences 96, 57-72.

Schröder-Ritzrau, A., Mangini, A., Lomitschka, M., 2003. Deep-sea corals evidence periodic reduced ventilation in the North Atlantic during the LGM/Holocene transition. Earth and Planetary Science Letters 216, 399-410.

Schröder-Ritzrau, A., Mangini, A., Freiwald, A., 2005. U/Th-dating of deep-water corals from the Eastern North Atlantic and the Mediterranean Sea. In: Freiwald, A., Roberts, C.N. (Eds.), Cold-Water Corals and Ecosystems. Springer, Berlin, Heidelberg, pp. 159-174.

Smith, J.E., Risk, M.J., Schwarcz, H.P., McConnaughey, T.A., 1997. Rapid climate change in the North Atlantic during the Younger Dryas recorded by deep-sea corals. Nature $386,818-820$

Stuiver, M., et al., 1998. Intcal98 radiocarbon age calibration: 24,000-0 cal BP. Radiocarbon 40 (3), 1041-1083.

Thornalley, D.J.R., Elderfield, H., McCave, N., 2009. Holocene oscillations in temperature and salinity of the surface subpolar North Atlantic. Nature 457, 711-713.

van Aken, H.M., Becker, G., 1996. Hydrography and through-flow in the north-eastern North Atlantic Ocean: the NANSEN project. Progresse in Oceanography 38, 297-346.

Van Rooij, D., et al., 2006. Quaternary sediment dynamics in the Belgica Mound province, Porcupine Seabight: ice-rafting events and contour current processes. International Journal of the Earth Sciences, doi: 10.1007/s00531-006-0068-6.

Van Rooji, D., Blamart, D., Unnithan, V., 2001. Cruise-report MD123 Geosciences: Leg 2, part GEOMOUND. Porcupine Basin and Rockall Trough, Off Western Ireland.

van Weering, T., de Haas, H., de Stigter, H.C., Lykke-Andersen, H., Kouvaev, I., 2003. Structure and development of giant carbonate mounds at the SW and SE Rockall Trough margins, NE Atlantic Ocean. Marine Geology 198, 67-81.

van Weering, T., shipboard scientific party, 1999. Shipboard Cruise Report R.V. Pelagia 64PE143: A Survey Of Carbonate Mud Mounds of Porcupine Bight and S. Rockall Trough Margins, NIOZ, Texel.

Vollweiler, N., Scholz, D., Müllinghausen, C., Mangini, A., Spötl, C., 2006. A precisely dated climate record for the past 9 kyrs from three high alpine stalagmites, Spannagal Cave, Austria. Geophysical Research Letters 33, 1-5. 
Wheeler, A.J., et al., 2005. Sedimentary processes and carbonate mounds in the Belgica Mound province, Porcupine Seabight, NE Atlantic. In: Freiwald, A., Roberts, J.M. (Eds.), Cold Water Coral Ecosystems. Springer Verlag, Berlin Heidelberg, pp. 571-603.

Wheeler, A.J., et al., 2007. Morphology and environment of cold-water coral carbonate mounds on the NW European margin. International Journal of Earth Sciences 96 , 37-56.

White, M., Bowyer, P., 1997. The shelf edge current northwest of Ireland. Annals of Geophysics 15, 1076-1083.
White, M., Mohn, C., De Stigter, H.C., Mottram, G., 2005. Deep-water coral development as a function of hydrodynamics and surface productivity around submarine banks of Rockall Trough, NE Atlantic. In: Freiwald, A., Roberts, J.M. (Eds.), Cold-Water Corals And Ecosystems. Springer, Heidelberg, pp. 501-514.

Williams, T., Kano, A., Ferdelman, T., Henriet, J.P., party, I.E.s., 2006. Cold-water coral mounds revealed. EOS 87 (47), 525-526. 